Conference proceedings $2^{\text {nd }}$ and $3^{\text {rd }}$ Regional Innovation \& Entrepreneurship Conference

\title{
Wonder-driven Entrepreneurship Teaching; when working with the ethical and existential dimension in professional bachelor education
}

\section{Finn Thorbjørn Hansen, Ph.D}

Aalborg University, finnth@hum.aau.dk

\section{Sine Maria Herholdt-Lomholdt}

VIA University College,smhl@via.dk

Abstract: This paper will in an overall and outlining way describe why the phenomenology of wonder and wonder-based approaches can become doorways for understanding the existential and ontological dimensions of entrepreneurship teaching.

Keywords: wonder, meaningfulness, innovation, entrepreneurship-education

\section{Introduction}

Contemporary research on creativity, innovation and entrepreneurship have now for a decade or more focused on social constructive, pragmatic, socio-cultural and socio-material dimensions of creative and innovative processes (Bager et al. 2010, Brinkmann \& Tangaard 2010, 2012; Ledwith \& Bessant, 2009; Sarasvathy, 2008; Bason 2012). New and innovative ideas are, following these approaches, understood as something individuals or professional communities of practices create in relation with specific others through product-, user- and design-driven innovation and different processes of ideation. Lately a more existential and philosophical-hermeneutic approach to innovation has been suggested. Verganti \& Öberg (2013) talks about a change from user- to meaning-driven innovation, 
Conference proceedings $2^{\text {nd }}$ and $3^{\text {rd }}$ Regional Innovation \& Entrepreneurship Conference

Madsbjerg \& Rasmussen (2014) about 'moments of clarity' transcending what can be captured by the socio-cultural and constructive approach, Scharmer and Kaufer (2014) talks about pre-sensing as a place for "hearing the call" from an emerging future and Hansen (2014) suggest an existential and wonder-driven approach to design-, innovation- and entrepreneurship processes.

We want to continue in line with this new framework of meaning- and wonderdriven innovation by focusing on the possible educational consequences of such an approach. Our empirical departure is our three-year phenomenological action research project: 'Wonder-based Entrepreneurship Teaching in Professional bachelor Education'. Ten senior lecturers in nursing and pedagogy from VIA University College, Denmark participated. The purpose was to investigate whether and how Socratic and philosophical dialogues and different forms of phenomenological and existential reflections in so-called 'Wonder Labs' could contribute to existing innovation- and entrepreneurship education in at least two ways: To deeply and existential root students in their profession and values and to bring students on the edge of their knowledge into the field of "not knowing but being".

\section{Wonder}

The phenomenology of wonder, Philosophical wonder, is different from curiosity, systematic analysing inquiry and critical reflection. The philosophical wonder is, as Hansen $(2008,2010 b, 2012,2014,2015 a)$ describes it, not as much an act or an effort of the subject as an ontological event and reaction that calls on us, while living our lives (Gadamer 2006; Rubenstein 2008; Vasalou 2012 ). We experience the philosophical wonder, when life meets us with severe beauty, goodness or truth and we - on behalf of this experience - may stop and rethink understandings we normally take for granted. The philosophical wonderment can be described as a special kind of thoughtfulness, restored to life from touching life-situations (see also Van Manen 2014).

Wonder then, can also grow from any kind of aesthetic experience, if we understand the aesthetic experience in a philosophical way, as a kind of existential and ontological experience (Jørgensen 2006, 2008, 2011). If we follow Jørgensen, the aesthetic experience can be characterized by the meeting of something greater than oneself - and a sensing of some kind of meaning or truth given to us by life. 
Conference proceedings $2^{\text {nd }}$ and $3^{\text {rd }}$ Regional Innovation \& Entrepreneurship Conference

In that sense, the phenomenology of wonder could be understood as a kind of dance between poetic dwelling and Socratic dialectics (Hansen 2012). In being in a fundamental wonderment we are under impression of both 'something' evocative that speaks to us and a philosophical questioning, which ask for what the mere analytical concepts cannot in logical and argumentative ways capture. Through this aesthetical, philosophical, dialectical and playful dialogue, which Socrates was so good at, we open ourselves for an ontological and silent dimension in our lives and professional practices. Thus the phenomenology of wonder is a phenomenology of both sensuous openness and philosophical presence ${ }^{7}$.

In professional bachelor educations in Denmark we mostly learn the student problem-identification and problem-solving skills. This is indeed a needed qualification but at the same time limits the extent of the students and our view. Great deals of the ongoing innovation- and entrepreneurship-teaching, also take such departure from "irritations" and dis-harmonies (e.g. Bager et al 2010, Digman et al. 2012).

With the phenomenology of wonder as an underlying tone and a wonder-based approach to innovation and entrepreneurship we try to take on another view. We do not think innovation and entrepreneurship from a 'meaning-making-paradigm' but from a 'meaning-receiving-paradigm' (Hansen, 2014) and instead of dis-harmonies we take our departure from experiences of harmony.

\section{A wonder-based approach to innovation and entrepreneurship}

In a former research-project, Hansen (2010a) introduced a model of "four voices" in the pedagogic of higher education. This model has recently been developed by Hansen (2014), to include four different views of innovation and entrepreneurship. At its basis, the model points out how different voices make four different educational rooms, as shown in figure 1:

1. First we see the voice of the System. This is a voice of both law and practice telling us about right, wrong and what a good professional

\footnotetext{
7 For an elaboration on how this kind of Socratic and wonder-based thinking can be unfold in a so-called Socratic and phenomenological-oriented action research approach, see Hansen, 2015b)
} 
Conference proceedings $2^{\text {nd }}$ and $3^{\text {rd }}$ Regional Innovation \& Entrepreneurship Conference is. The reality is taken for granted and the society and market sets the agenda for what the professionals are supposed to do.

2. Next we see the voice of the Profession, expressing theory and empirical knowledge foundations of the profession.

3. The third voice is the Personal voice engaged in questions of "who and where I am in the voices of the Systems and Profession?" and in developing some kind of personal touches and style.

4. At last we have the voice of the Subject Matter. This voice is connected to a call and a sense of meaningfulness or dialogue with a phenomenon. This is the place of the artist or philosopher who listens and step aside in order for the matter, phenomena or materials self to speak. But, so easily the Professional voice and the voice of the System can stand in the way of the ontological voice of being or the phenomena itself. Even the Personal voice, if it is too self-absorbed, can weaken our sense of the voice of the Subject matter.

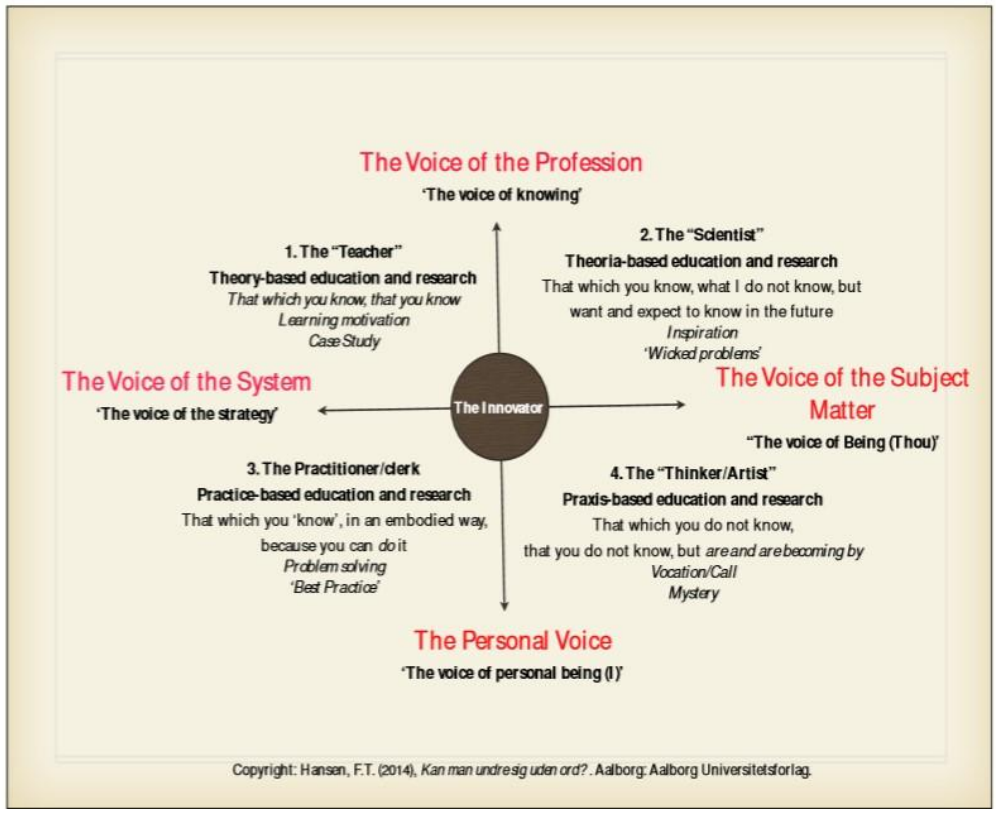

Figure 11

The four voices 
Conference proceedings $2^{\text {nd }}$ and $3^{\text {rd }}$ Regional Innovation \& Entrepreneurship Conference

As the model shows, the four voices can open up different rooms for innovation and entrepreneurship.

In room number 3, we see a commercial and problem-solving understanding of innovation and entrepreneurship. In this understanding the driver for innovation and the innovation-management comes from outside the profession, e.g. the user, the politicians or managers. In this room innovation seeks to solve specific problems in new ways but within the known paradigm.

In room number 1 , the driver for innovation is science. Innovation is in this sense the application and translation of new research into practice. This view is a quite common understanding of innovation e.g. in nursing (Herholdt-Lomholdt 2013).

Where rooms 1 and 3 relies on a world of the known and a kind of no-risk situation, rooms 2 and 4 are looking into the unknown and risk-taking thinking and actions. In these rooms we see a kind of inner steering and breaking through the common paradigms in research and practice. This could be rooms for radical innovation, as they seem to make transcendence possible.

In room 2, we see a search for wicked problems and questions, that contemporary research and professional knowledge is not yet capable of dealing with. In this room the driver of innovation is an inspiration from the Subject matter but seen through the epistemological and knowledge lenses of contemporary research by looking upon the matters we know that we do not know yet.

In room 4, a wonder-based approach to innovation expresses itself. In this room we meet phenomenon's arising from practice through our being-in-the world and in an original sense without analysing or theorizing. We try, as mentioned above, to hear the call from practice and listen to the wonders of life. This room is a room seeking for the matters which we don't know that we don't know - but already - in some peculiar way, are called by as beings. This might be a place for sensing the unknown but emerging future. When entering this fourth room of wonderment and fundamental not-knowing, new ideas and meanings are not solely created by human beings. Meanings are merely understood as a call and as something given to us. This implies a shift from an understanding of innovative ideas and meanings as cocreated to a new paradigm of meaning-receiving. This is a field of new beginnings which we theoretically approach through the lenses of existential phenomenology (Merleau-Ponty, Løgstrup, Marcel), philosophical hermeneutics (Gadamer, Ricoeur, Risser) and what Max van Manen describes as 'the phenomenology of practice' (Van Manen 2014). 
Conference proceedings $2^{\text {nd }}$ and $3^{\text {rd }}$ Regional Innovation \& Entrepreneurship Conference

Through our action-research project, we have tried to bring students from professional bachelor educations and ourselves into this fourth room. On behalf of eight teaching experiments in spring 2014 we have developed a model for wonderbased entrepreneurship education named the 'wonder-fisch'. In this paper we will only concentrate on some of the key-aspects of the pedagogic movements in our wonder-based approach.

\section{Wonder-driven entrepreneurship teaching}

First we separate the process of innovation and entrepreneurship into two connected parts - a pre-ject and a pro-ject (see also Darsø 2011). The pre-ject is a place for sensing and listening to a call and wonder through dialogues, reflections and longing. To let people reflect on what they are really longing for in their life and professional work on a more existential level is, we have now experienced, a very inspiring springboard for new and deeper questions. The pro-ject is a place of making things happen by following a now qualified wonder and longing, drawing on available resources, making plans and realization.

In this paper we concentrate on the pedagogic of the pre-ject. The objectives of the pre-jet is to get in contact with the call from practice, listen to the meaningfulness of life - what the students really find precious - and on behalf of this formulate a longing.

In the pre-ject, we have been working in "wonder-labs" by inspiration of "Kundskabsvaerkstedsmodellen" (Erstad \& Hansen 2013, Hansen, 2014) . Basically we have done 4 different pedagogical movements through dialogues - and in some cases through music and drawings. These are:

1. The phenomenological turn and wonder

2. The Hermeneutic turn

3. The Socratic and dialectic turn

4. The existential and phronetic return the 'cave of our ordinary living'"

The fourth phase (the phronetic and existential return) is present as a kind of bridge to the pro-ject, where the three first turns are settled in the pre-jet.

See også the research unit, Wonder Lab, at Centre for Dialogue and Organization, University of Aalborg, Denmark

9 For a richer and in-depth description of these movements in the Wonder Lab, see Hansen 2015a 
Conference proceedings $2^{\text {nd }}$ and $3^{\text {rd }}$ Regional Innovation \& Entrepreneurship Conference

The phenomenological turn is a turning towards a touching situation in practice. All students are asked to tell (or e.g. draw) a real-life situation connected to their profession that made some kind of impression on them. The story has to be openended in the sense that it is forbidden to identify problems, do problem solving or to have any point telling the story beforehand. The students are asked to listen with an open heart and mind to the stories of each other. By telling these stories, we often see the vulnerability of the students and at the same time their proudness - and values. From these often remarkable phenomenological stories we try to open the students and ourselves for genuine wonderment and a stepping into a community of wonder. As mentioned above, wonder is characterized by deeply questioning our pre-understandings and the "taken for granted" - by the silent listening for the meaningfulness of life. When wonder happens to us, we take a step into the open and thereby experience the possibility of enlarging our horizon or even sense a radical break through. Philosophical and aesthetical wonderment then, can be a doorway into the fourth room of innovation and is grounded both existential and ontological.

But, to enlarge our horizon we need a dialogue with something or someone outside our subjective and cultural views. Therefore the hermeneutic turn is of importance by letting our wonder meet humanity's Grand Stories about themes and questions that came up within the personal story. Great stories refer to philosophy, arts, music and other kinds of artistic comprehensions of life that are known by the majority. In a dialogue around these great stories, we do have the opportunity to discover and even break through some of our historic and cultural pre-understandings.

The Socratic and dialectic turn refers to the way we speak to each other in the community of wonder. As Hansen (2008) with a reference to the German philosopher Hannah Arendt points out, we can learn from the Socratic way of thinking and questioning. What Socrates did, was to ask human beings to think by themselves instead of downloading the thoughts of others. As educators in the preject, we ask for the student's independent and original thoughts and beliefs in a friendly and playful atmosphere. And at the same time, we tease, provoke and search together for the limitations of these thoughts. In truth - but also surprisingly - it seems to be a great challenge for students of today, to think by themselves. Students in professional bachelor education have for several years been learning to replicate the knowledge and research of their profession. To think for themselves seems to be both difficult and way out of comfort zone.

The pre-ject ends up defining a new qualified longing and often also a new but deeper wonderment. This longing, a longing for some kind of fulfilment of life, will be an important leading star of the pro-ject, and is now ready to meet reality for 
Conference proceedings $2^{\text {nd }}$ and $3^{\text {rd }}$ Regional Innovation \& Entrepreneurship Conference

further qualification, ideation and realization. In the pre-ject the students develop and connect their own values and thinking to processes of innovation and entrepreneurship, which makes us talk of it as an existential turn in entrepreneurship-education. At the same time, the students also listen to something experienced as a wondrous "call" from practice. This can be described as an ontological turn in entrepreneurship education.

\section{A vision}

The existential and ontological turns in entrepreneurship education have implications of importance. In professional bachelor education, the phronetic judgement and ethical dimensions are at stake all the time. We do not connect the Aristotelian concept of phronesis to a practical cleverness in getting things done as quick and effective as possible in an intuitive way. Instead we follow Gadamer $(1986,2006)$ when he connects the Aristotelian concept of phronesis to our existential and ethical awareness of being-in-the-world having an ontological musicality for the voice of being, or voice of what the situation, relation or phenomena is calling us to do. This demands a readiness to 'stand in the openness'. Every time a nurse meets a patient, every time a pedagogue meets a child, she has to make some kind of decisions and create unique solutions, and these decisions draws on her values and ability to judge. With a meaning-receiving paradigm instead of a meaning-making paradigm - and with a wonder-driven entrepreneurship education in professional bachelor education - these solutions might tend to draw on ontological-based meaningfulness given to us by life itself, rather just on an epistemology of practice and the 'functionality', that the system, profession or pragmatic and problem-solving practice calls us to do. To get this musicality for the voice of being or Subject matter requires a training to meet other people and situations with the special kind of ontological attentiveness and wonderment.

If we understand the phronetic judgement as a key competence in professional bachelor educations, this would mean, that entrepreneurship education would not only be for the few enterprising students starting up a business - but for all of them. But then we have to think differently about how to bring in the existential and ontological dimensions into entrepreneurship teaching. That is: To see the wonder in daily life and profession as a new source for radical innovation and entrepreneurship teaching. 


\section{References}

Bager, L.T., Blenker, P., Rasmussen P. \& Thrane C., 2010, Entreprenørskabsundervisning - proces, refleksion og handling. Aarhus: Aarhus entrepreneurship Centre.

Bason, C. 2012, Public managers as designers. In: Ledelse og erhvervsøkonomi vol. 76 No. 4 p. 47-69.

Brinkmann, S. \& Tanggaard, L. 2010. Toward an epistemology of the hand. Studies in Philosophy and Education, Vol. 29, No. 3, p. 243-257.

Brinkmann, S \& Tanggaard, L. 2012. "Hvad vi taler om, når vi tale rom kreativitet. Nordiske Udkast, Vol. 40, No. 2, p. 3-15.

Darsø, L. 2011, Innovationspadagogik. Kunsten at fremelske innovationskompetence. Forlaget samfundslitteratur.

Digmann, A., Jensen, K.E, Jensen, J.P. 2012, Vi er på vej. Offentlig innovation 2.0. København: Gyldendal business.

Erstad, I. \& Hansen, F.T (eds.) 2013, Kundskabsvaerkstedet - å se det levende $i$ en praksis. Oslo: Universitetsforlaget.

Gadamer, H.-G. 1986, The Idea of the Good in Platonic-Aristotelian Philosophy. New Haven, Yale University Press.

Gadamer, H.-G. 2000. Truth and method. London: Contiuum.

Hansen, F.T. 2008, At stå I det åbne. Dannelse gennem filosofisk undren og ncervcer. København K: Hans Reitzels forlag.

Hansen, F.T. 2010a. Filosofisk vejledning og praktisk kundskab $i$ professionsuddannelser. Forskningsrapport (365 sider). DPU, Aarhus Universitet. Download på: https://app.box.com/s/s92t2hlb91z1esh1hnr6

Hansen, F.T. 2010b. The Phenomenology of Wonder in Higher Education. In: Malt Brinkmann (ed.), Erziehung. Phänomenologische Perspektiven. Würzburg: Königshausen \& Neumann. (p. 161-178).

Hansen, F.T. 2012. "One Step Further: The Dance between Poetic Dwelling and Socratic Wonder in Phenomenological Research. Indo-Pacific Journal of Phenomenology, Vol. 12 (July, Special Edition), p. 1-20. 
Conference proceedings $2^{\text {nd }}$ and $3^{\text {rd }}$ Regional Innovation \& Entrepreneurship Conference

Hansen, F.T 2014, Kan man undre sig uden ord? Design- og universitetspcedagogik på kreative uddannelser - med Designskolen i Kolding som case. Aalborg: Aalborg Universitetsforlag.

Hansen, F.T. 2015a, The Call and Practice of Wonder: How to evoke a Socratic Community of Wonder in Professional settings. In: Michael Noah Weiss (ed.), The Socratic Handbook. Vienna: LIT Verlag, p. 217-244.

Hansen, F.T. 2015b, The Philosophical Practitioner as a Co-Researcher. In: L. Amir \& A. Fatic (eds.), Practicing Philosophy. Cambridge, Cambridhe Scholars Press, p. 22-41

Herholdt-Lomholdt, S.M. 2013, Skønne øjeblikke i sygeplejen - en kilde til innovation? En faenomenologisk undersøgelse af aestetiske øjeblikke og disse øjeblikkes forhold til sygeplejefaglig innovation. (Ph.d. projektbeskrivelse).

Jørgensen, D. 2006, Skønhed. En engel gik forbi. Aarhus: Aarhus Universitetsforlag

Jørgensen, D. 2008, Aglaias dans. På vej mod en cestetisk tcenkning. Aarhus: Aarhus Universitetsforlag.

Jørgensen, D. 2011, "The experience of immanent Transcendence". Nordisk tidsskrift for kunst og kristendom 2010-11. p. 35-52

Ledwith, A. \& Bessant, J. 2009. Managing Innovation in SME's. Cambridge: Cambridge Scholar Publishers

Madsbjerg, M. \& Rasmussen, C. 2014. The Moment of Clarity. Using the Human Sciences to Solve Your Toughest Business Problems. Harvard Business Review Press.

Rubenstein, M.-J. 2008, Strange Wonder: The closure of metaphysics and the opening of awe. New York: Columbia University Press.

Sarasvathy, S. 2008. Effectuation: Elements of Entrepreneurial Expertise. (New Horizons in Entrepreneurship Series). Edward Elgar Publishing.

Scharmer, O. \& Kaufer, K. 2014, Ledelse fra den spirende fremtid. Fra ego-system til øko-system økonomier. Randers, Forlaget Ankerhus. Translated from Leading from the emerging future. From Ego-system to Ecosystem economies.

Van Manen, M. 2014. The Phenomenology of Practice. Walnut Creek, California: Left Coast Press. 
Conference proceedings $2^{\text {nd }}$ and $3^{\text {rd }}$ Regional Innovation \& Entrepreneurship Conference

Verganti, R. \& Öberg, Å. 2013, Interpreting and envisioning - A hermeneutic framework to look at radical innovation of meanings. In: Industrial Marketing Management vol. 42, pp. 86-92.

Vasalou, S. (ed.) 2014, Practices of wonder: Cross-disciplinary perspectives. Eugene, Oregon, Pickwick Publications. 